Ansell N (2004) 'Secondary schooling and rural youth transitions in Lesotho and Zimbabwe' Youth and Society 36(2) 183-202

Secondary schooling and rural youth transitions in Lesotho and Zimbabwe

Nicola Ansell, Department of Geography and Earth Sciences, Brunel University

Submitted to Youth and Society

Address for correspondence

Dr Nicola Ansell

Department of Geography and Earth Sciences

Brunel University

Kingston Lane

Uxbridge

UB8 3PH

UK

Phone: $01895274000 / 01895203215$

Fax: 01895203217

Email: nicola.ansell@brunel.ac.uk 


\title{
Secondary schooling and rural youth transitions in Lesotho and Zimbabwe
}

\begin{abstract}
Based on case studies centred on two rural secondary schools in Lesotho and Zimbabwe, this paper examines the gendered impacts of schooling on young people's transitions to adulthood. School attendance is shown, first, to disrupt the conventional pathways to adulthood: young people attending school may leave home sooner than they otherwise would, and take responsibility for their day-to-day survival, while marriage and childbearing are often delayed. More significantly, secondary schooling reflects, and contributes to, a growing sense that adulthood itself is not fixed. An alternative version of adulthood is promoted through schools in which formal sector employment is central. Yet while young people are encouraged to opt for, and work towards, this goal, only a minority are able to obtain paid employment. The apparent possibility of determining one's own lifecourse serves to cast the majority of young people as failures in their transitions to adulthood.
\end{abstract}

Key words: secondary education; southern Africa; rural youth

Nicola Ansell is a lecturer in human geography at Brunel University. Her research interests focus on young people in southern Africa. 


\section{Secondary schooling and rural youth transitions in Lesotho and Zimbabwe}

Despite rural poverty and increasing fees, a substantial proportion of rural youth in both Lesotho and Zimbabwe attend secondary school. These young people inevitably experience different patterns of transition to adulthood compared with their less educated peers. The paper begins by outlining historical patterns of youth transition among the Basotho of Lesotho and Shona of Zimbabwe. Case studies of two rural secondary schools and their surrounding communities are used to examine how secondary schooling impacts on youth transitions. In conclusion, the paper reflects on young people's agency in their transitions to adulthood, drawing on Western youth transitions research.

\section{Youth transitions in Lesotho and Zimbabwe: a brief history}

That there is a growing body of academic literature concerned with youth transitions in the West reflects recognition that there is no singular point (such as the age of 18) at which a young person becomes an adult (Jones and Wallace 1992). Rather, becoming an adult is a protracted process during the course of which most young people cross (and sometimes re-cross) a series of boundaries. The boundaries that have received most attention are leaving school, starting work, leaving home, setting up an independent home and beginning a family. These are usually represented as a series of parallel transitions (Jones and Wallace 1992; McDowell 2002).

The experiences of young people approaching adulthood in rural Lesotho and Zimbabwe differ from those of their Western counterparts, partly reflecting historical patterns of transition among Basotho and Shona peoples. Among the Basotho, entry into adulthood was marked by a formal initiation process. This was 'a one-class-at-a-time, unisex, formal, group instruction period - lasting from two to eight months' (Montsi 1978:92), where young people 'learned cultural values and philosophy, personal and family responsibilities, and 
duties to one's clan and people' (Ministry of Education 1982:1). The culmination was a ceremony that included circumcision for boys and genital cutting of girls. Initiation was never, however, the only significant moment in a young person's transition to adulthood. Furthermore, not every African society practised formal initiation: among the Shona the skills and knowledge deemed necessary for adulthood were imparted informally.

Marriage has long been pivotal within southern African youth transitions, representing an abrupt change of social, economic and legal status. Men were traditionally allocated farmland when they married, enabling them to provide for their own, and their families' economic needs. Legally, marriage gave men majority status. Although a girl became a 'woman' upon marriage, her legal status changed little. Even today, under common law rural Basotho women remain perpetual minors, transferred from their fathers' authority to their husbands' upon marriage (Gill 1994). In Zimbabwe, customary law restricts women from owning land, but the Legal Age of Majority Act (1982) grants women over 18 certain legal rights (Gwaunza 1995). Both societies are patrilocal, hence women, unlike men, traditionally leave their parental home to join their husbands' families. Only following the birth of a child would a couple acquire their own house.

Traditional youth transitions in Lesotho and Zimbabwe, then, involved multiple elements and were highly gendered, but the pattern was fixed and almost universal. Although young people doubtless exercised agency in relation to details, choice concerning the overall pathway was minimal, and there was no significant risk of 'failure'. ${ }^{1}$ While traces of these practices remain in rural areas today, they are no longer considered a universal template.

Over the past 120 years, as southern Africa became tied in to the global economy, patterns of youth transition changed. Basotho men found employment in South African 
gold and diamond mines; Zimbabwean men in factories, commercial farms and mines. Such employment became part of the adult identity to which young men aspired (Ferguson 1990). As in Western Europe, entry into formal waged work was a new form of initiation into adulthood. Among women there was, until recently, much less expectation of paid employment, particularly in rural areas. Male labour migration was sustained in part by reproductive work performed by rural women. Thus adulthood for women implied subsistence agriculture and childrearing.

Today, with global economic restructuring, employment opportunities in the traditional migrant labour sectors are diminishing (Gay et al 1995). Nonetheless, the prospects of supporting a family on subsistence agriculture alone remain slim (Batezat and Mwalo 1989; Gay et al 1995). Hence there is a growing expectation of both girls and boys that a secure future requires paid employment, preferably in the formal sector. This, in turn, increasingly demands secondary education.

\section{Rural secondary education in Lesotho and Zimbabwe: the case study schools}

In Lesotho about $50 \%$ of young people begin secondary school, but the proportion in rural areas, especially in the sparsely populated mountains, is lower. Furthermore, only a minority remain in school for the five years required to complete the Cambridge Overseas School Certificate $\left(\operatorname{COSC}^{2}\right)$. Enrolment rates are higher among girls; a situation that relates partly to the employment of boys as shepherds, and partly to the historical availability of minework to minimally educated men.

Mahloko ${ }^{3}$ High School is a Catholic school, fairly typical of Lesotho's rural schools, located in the Maluti Mountains, three hours by bus from the capital, Maseru. Most of its 240 students come from elsewhere in Lesotho and reside in self-catering hostels at the 
nearby mission. The school has limited resources with no electricity, but ten qualified teachers, adequate classroom facilities and a reasonable supply of textbooks.

In Zimbabwe, ${ }^{4}$ secondary education grew dramatically post-independence: enrolment expanded ten-fold between 1979 and 1989 (Bennell and Malaba 1993). Fees are much lower than in Lesotho, and more children enter secondary school (about $70 \%$ of the cohort) and complete the four-year course culminating in $\mathrm{O}$ Levels. ${ }^{5}$ Both enrolment and examination pass rates are higher among boys than girls, reflective of the expectation that men should be breadwinners and need education to obtain employment.

Ruchera Secondary School is an average rural Zimbabwean school. As a District Council day school with 500 students, it caters for a local catchment in which most children proceed to secondary education. The area is densely populated and slightly more affluent than average for rural Zimbabwe. Compared with Mahloko, Ruchera takes children from a wider range of economic backgrounds. The school facilities are of slightly lower standard than at Mahloko: classrooms are poorly furnished and there is neither electricity nor running water. The school has 21 teachers, most with teaching qualifications.

\section{The research}

A selection of largely qualitative methods were employed over a period of 3-4 months at each school. Single sex focus groups were held with older students, meeting for up to two hours on 3-7 occasions to discuss wide-ranging issues. The students who completed Form E at Mahloko in 1996 were traced 9 months later and the 13 girls were sent a postal questionnaire. Younger children wrote compositions on a choice of topics relating to education and their future aspirations. All teachers were interviewed along with school managers and governors. These methods were supplemented by participant observation and textual analysis of textbooks, syllabuses, exams and policy documents. The school- 
based research was conducted in English, and all quotations below are verbatim. Interviews were also conducted in the local communities with all formally employed women, key decision-makers and all adult woman in two small villages (Ha Rateme near Mahloko and Muzunga near Ruchera). Where necessary a research assistant translated.

\section{Secondary education as an intervention in youth transitions}

Students seldom enter rural secondary schools in southern Africa below the age of 14 . Those completing the secondary cycle at Mahloko averaged 19 (female) or 21 (male) years; most at Ruchera were 17 or 18 . Thus many young people are in school during the period when they would otherwise cross boundaries that conventionally accord adult status: marriage, childbearing, setting up a new home. Inevitably, therefore, schooling intervenes in their transitions to adulthood.

That young people who remain in school longer marry later, and have children later has long been recognised (King and Hill 1993; Psacharopoulos and Tzannatos 1991; Schultz 1993). Although some students marry while at school, this is unusual, and students who become pregnant are generally expelled. Those wishing to complete school postpone these transitions.

Schooling also intervenes in young people's transitions to work, inhibiting economic activity. In Africa, however, a simple transition from a work-free childhood to an adulthood characterised by full-time paid work is unusual. Children participate in domestic work from an early age, and many work outside the home, sometimes for pay. Many Basotho boys, for instance, work as shepherds from as young as seven, taking responsibility for livestock, sleeping away from home, fending for themselves, initially with other boys, but later alone. The tasks performed by children are not necessarily distinct from those adults 
undertake. Although schooling and full-time work are mutually exclusive, most students continue to perform domestic and agricultural chores for their families outside school time.

One transition that may be accelerated through attendance at secondary school is leaving home. For many young people, attending boarding school entails leaving their kin for the first time. Most girls and boys at Mahloko High School stayed in self-catering hostels and took full responsibility for their day-to-day survival, shopping, cooking and washing their own clothes: activities usually gendered female. While some found budgeting difficult, and ran out of money before the end of the month, most appreciated the freedom. One boy commented: 'We can do whatever we want at the time we want. No one forces us to do everything.' Many older students rented rooms independently nearby. Similarly, 'bushboarding' is common in remote areas of Zimbabwe: boys build makeshift accommodation to avoid walking long distances daily.

It is notable that the senior students at Mahloko High School, while exercising considerable independence, felt insufficiently adult to make major decisions about marriage or careers, but expected their parents to fulfil this role. One girl explained: 'If I can decision myself I will become like a wild animal.' Similarly, some students at Ruchera felt the Legal Age of Majority Act accorded them adult status too soon (Extract 1). 


\section{Extract 1: focus group}

Chido: I think it's not good because I think I'm still 18 - I will be still in need of my parents' care. Also I will not be able to care after myself because I will not be going - I will not be employed because I will be still just after school before my results.

Rudo: And we will realise that if we will follow the Majority Act, that means that we are realising that most of the girls or most of the boys, they are going astray because they are following that Majority Act. And in that way, um, they will say to their parents 'I'm now I'm over 18 so I should do what I want and I should decide everything for myself. This is leading them - this is leading people, er, peoples astray ... [Girls' focus group, Ruchera Secondary School, Zimbabwe].

\section{Redefining adulthood: the centrality of paid work}

Attendance at secondary school not only intervenes in young people's transitions to adulthood; it is geared towards an alternative version of adulthood in which paid employment is central, as hinted at in Extract 1. While this version of adulthood does not derive exclusively from schooling, and is not entirely new, the expansion of secondary education in both Lesotho and Zimbabwe both reflects and reinforces its prominence in the aspirations of rural people. Adulthood is not, as Brannen and Nilsen (2002) point out, the unproblematic concept that much youth transitions research assumes.

The primary purpose of secondary education according to most parents, students, teachers and education officials in Lesotho and Zimbabwe is to enable young people to obtain formal sector work. Among mothers from the Mahloko area, the most commonly stated reason for sending children to secondary school was to gain employment. In both communities women told me 'life, nowadays, depends upon education'. Most said they would feel hurt, or that they had wasted their money, if their children dropped out of secondary school, or failed COSC/O Levels and could not find work. 
Most teachers at Ruchera similarly described the purpose of education in terms of employment. Many, as in Extract 2, considered education to have a purpose only for those students passing five O Levels.

\section{Extract 2: interview}

... Otherwise, if you don't have that secondary education, there is nothing you can do which is very productive. Otherwise, you can't be employed without O Level passes. You can't do anything.

[Student teacher, Ruchera Secondary School, Zimbabwe].

Students recognised various benefits of education, but presented with a hypothetical scenario where people are paid equally regardless of education or employment, the majority in all focus groups argued that obtaining secondary education would be pointless (Extract 3). Of 28 Ruchera students, both male and female, whose compositions answered the question 'Why should children in Zimbabwe go to school?', 26 wrote about jobs, often as the first point. Secondary education is clearly viewed as preparation for an adulthood in which paid employment is central.

\section{Extract 3: focus group}

Josiah: [...] Of course, knowledge, you want to acquire knowledge, but knowledge comes after. The most important factor we come for school is that we want better lives, and better lives can be acquired through by earning better jobs.

[Boys' focus group, Ruchera Secondary School, Zimbabwe].

This version of adulthood is seen to apply equally to boys and girls. No student suggested that women should not work: Extract 4 gives a typical view. This partly relates to two factors internal to the school. First, students understand the purpose of education to be 
employment: if they are not to seek employment, why are girls in school? Second, education, and by extension, employment as its intended outcome, is subject to a pervasive discourse of 'equal rights' in school (Ansell 2002).

\section{Extract 4: composition}

To flash back to the way women lived at the past. We can saw a number of things which were not fair. Fo [sic] example. Women were not able to seek for job. Man only were the one who had that chance.

[Boy, Form 3A, Ruchera Secondary School, Zimbabwe].

Wage-earning adults are valued as providers for their families. Although traditionally boys' responsibility (and hence a reason why, especially in Zimbabwe, boys were educated in preference to girls), many parents observed that girls are more likely to contribute financial support, if they find work (Extract 5). Many students like Mpho (Extract 6) feel duty bound to obtain employment to help their parents. Married women are also expected to provide for their own families, spending their income on their children while their husbands may spend theirs on personal luxuries, most frequently alcohol (Vukasin 1994).

\section{Extract 5: interview}

-Do you think it's more important for girls to go to school than for boys?

-It's more important to send a girl.

-Why's that?

-Boys are useless. All they do is make girls pregnant and smoke dagga. A girl, when I am ill, my daughter comes with groceries.

[36-year-old woman, Ha Noko, Lesotho]. 


\section{Extract 6: composition}

After I have finished my Form E I like to go to university because I wanted to be a nurs [sic] and I want to help my parents if I can have some jobs to do because I saw that they work hard in order to help me to be educated.

[Mpho [f], Form D, Mahloko High School, Lesotho].

Paid employment not only assures higher material living standards for the household: it also provides economic security for the individual. This ties into a distinctive conception of adulthood as individual and independent, a view that is particularly significant to young women. Women are not entitled to fields in either community unless they marry, and even those who marry working men seldom receive reliable economic support. Although not all working women control their own wages (legally, married women in Lesotho cannot open bank accounts without their husband's signature), an income generally reduces dependence on men. Economic independence was a particular concern in Lesotho, where men often fail to maintain rural families during their prolonged (sometimes permanent) absences (Extract 7). The concern of Basotho mothers to educate their daughters as a precaution against marriage failure has been noted (Gay 1982; Mueller 1977). Women in Muzunga, too, see employment, and the independence it brings, as a better option for their daughters than marriage (Extract 8). While no women suggested education might allow a daughter to leave an abusive husband, girls in focus groups at Ruchera were aware that if they had employment, this would be an option. ${ }^{6}$ 


\section{Extract 7: postal questionnaire}

I am not married. I do not think I will get marriage before I can work by my self. I have told you when you were here at Lesotho that the wivies [sic] who are not working they suffer because they husband refuse to give them money.

[Nketheleng [f], former student, Mahloko High School, Lesotho].

\section{Extract 8: interview}

-[...] if you only have money for one to go [to secondary school], will it be a girl or a boy? -Both.

-Why is it important?

-If it is a girl she will have the knowledge. She will not get married. She will just work.

[34-year-old woman, Muzunga, Zimbabwe].

Adults in paid employment are also considered free to live apart from their families, a situation that in the past applied only to men. Paid work, whether urban or rural, is usually located away from home. Of 20 educated women in formal employment interviewed in Mahloko, only two lived with their husbands. The early taste of 'migration' students at Mahloko High School experience may reduce inhibition towards later migration. Living apart from parents, spouses and in-laws, young people may exercise greater autonomy, as students recognised (Extract 9).

\section{Extract 9: focus group}

Puseletso: [I want to live] away from my parents, because they are very troublesome. [...] They will come inside my house and say 'You'd better do this and this'. That's what I hate. I want to control myself, with my husband.

[Form E girls, Mahloko High School, Lesotho]. 
Young people attending secondary school (are expected to) aspire and work towards an adulthood in which employment is central, enabling them to become independent individuals and also providers for their families. Youth transitions research in the West has been criticised for 'economism' - for being bound up with the demands of the labour market, young people being seen as moving from immature unemployable children to independent employable adults (Cohen and Ainley 2000). Yet in southern Africa, access to paid employment is widely seen as fundamental to a particular understanding of adulthood as a time of independence. Furthermore, this version of adulthood is clearly much less gender-differentiated than that which characterised youth transitions in the past.

\section{Secondary education and access to paid work}

That secondary education encourages young people to aspire to a work-centred version of adulthood does not mean it necessarily assists young people to obtain paid work. Access to employment depends on a range of factors, some of which schools can assist with and some that are structural and can be changed only through shifts in national/international policy and practice. Both the education system and various structural constraints make it especially difficult for rural youth and young women in particular to obtain paid employment.

Neither secondary school offers a truly vocationally relevant curriculum. Literacy and numeracy skills may be useful in clerical posts, or in obtaining further training; science, accounts and commerce provide knowledge applicable in certain jobs. Only agriculture equips students for manual work, but in Lesotho there is virtually no paid agricultural employment. Students who succeed in secondary school have generally acquired attitudes valued by employers, including hard work, persistence and conformity. Whether 
or not skills for formal sector employment are provided is, however, largely irrelevant, as employers select on the basis not of skills but possession of certificates.

Secondary education in Zimbabwe and Lesotho facilitates the selection of a few individuals for participation in very restricted formal sector labour markets. In Zimbabwe for instance, only 15-30,000 new jobs are created annually, shared between over 300,000 school leavers (Chavunduka 1991). Selection is achieved through public examinations, which provide a minority of school leavers with certificates. In 1996 30,148 Zimbabweans obtained five or more O Levels (ZIMSEC 1996), the minimum qualification for employment. Secondary schools do little to assist students to become self-employed or to create jobs. Although education enables some individuals to obtain paid work, it does little to expand the number of jobs available, merely catering to the demands for labour in the existing labour market (Dore 1976; Martin 1982).

Possession of a certificate does not guarantee a young person employment: there are other requirements, including information. At Ruchera Secondary School the Guidance and Counselling (G\&C) programme incorporates vocational guidance (interests and aptitudes; job requirements; types of employer; finding out about job and training opportunities; and applying for jobs). However, G\&C, as an unexamined syllabus, has a low priority in the school. At Mahloko High School no formal careers guidance is offered.

Particular difficulties face rural youth in accessing employment. The number of students obtaining certificates from rural secondary schools is very low. At Ruchera Secondary School 5\% or candidates passed 50 Levels in 1996, compared with a national figure of 20.7\%. At Mahloko the $13.6 \%$ pass rate compared with a national average for 1994 of $38.3 \%$. This discrepancy relates to a number of factors: rural schools are poorly equipped compared with those in towns and more prestigious boarding schools; it is difficult to 
attract qualified, committed teachers to places lacking electricity, telephones and running water; rural children have fewer benefits outside school, and most undertake domestic work while attending school. Rural youth who do gain certificates face difficulties finding out about employment opportunities in places that receive no newspapers and do not (in the case of Mahloko) have telephones.

Young women also face greater difficulties than young men in obtaining work. In Zimbabwe girls achieve considerably fewer examination passes than boys. Only $34.9 \%$ of those achieving five or more O Level passes in Zimbabwe in 1996 were female (ZIMSEC 1996). This is attributable to several factors, including domestic tasks that prevent girls from devoting sufficient time to study. Characteristics of the school environment can also make it less likely that girls will obtain academic qualifications. Some teachers believe girls are less able than boys and in some Zimbabwean schools academic subjects are only available to the male-dominated top streams at Forms 3 and 4 (Gordon 1995).

Qualifications alone do not guarantee girls employment. Even in Lesotho, however, where girls are relatively successful academically, a certificate in the hands of a woman is not equivalent to a certificate in the hands of a man. Although girls achieve more COSC passes than boys, they do not find paid work easily. In a study of 1985 and 1988 Form 4 leavers in Zimbabwe, 'among school-leavers with the same number of $O$ Level subject passes, consistently higher percentages of males were in wage employment [in 1991] than females' (Bennell and Ncube 1994:307).

Paradoxically, the view that education is for employment is sometimes undermined in school. Working women are not always portrayed in a positive light: the image presented in Extract 10 is unlikely to inspire girls to become 'career women'. The Lesotho textbook in which this poem appears does not promote discussion of whether it is reasonable to 
describe a woman in this way, or consideration of why a man is not described in similar terms. $^{7}$

\section{Extract 10: English textbook}

\section{Career Woman by Charles Mungoshi.}

Thirty-five and very plain

she is learning to settle down

to her underpaid job as a clerk typist

in some obscure firm of lawyers in the city.

$[\ldots]$

Thirty-five and childless

she is painfully coming to terms with reality

quietly sinking down in the centre

of her age's demands and limitations

$[\ldots]$

(Dawson 1988:94).

Given such mixed messages, it is perhaps unsurprising that although no boys suggested that, in principle, women should not work, some believed men's employment should take priority. Some boys at Mahloko argued they should work while their wives looked after the children, because '... here in Lesotho, the women get the jobs which have the lowest money'. This pragmatic reason is underlain by ingrained negative attitudes towards men's involvement in childcare.

Furthermore, despite a general consensus that educated women should work, they are seldom expected to find employment outside traditional service occupations. A Commerce textbook (Matindike 1986), typical for Zimbabwe, depicts women (who appear with only 
half the frequency of men) as consumers, or in employment conforming to gender stereotypes. A Development Studies textbook used in Lesotho offers information on various jobs and how to qualify for them, described by a fictional occupant of the post: policeman (male); teacher (female); nurse's helper (female); sales assistant (male) (Monaheng n.d.:49). Careers advice from teachers provides similar suggestions. While many girls argue that in principle, women and men should perform the same jobs, their own aspirations and actions tend to conform to stereotype. By limiting the careers they will consider, girls restrict their potential to find employment.

\section{Outcomes for rural students: failed transitions?}

Most students in Lesotho drop out of secondary school before they reach form E; in Zimbabwe the vast majority fail to obtain five $\mathrm{O}$ Levels, and many are awarded a $U$ (Ungraded) in each subject. Little attention is given to these students by teachers, or in the general discourse of the school. Teachers at Ruchera were unrealistic about their students' prospects, or concerned only about the most able (Extract 11).

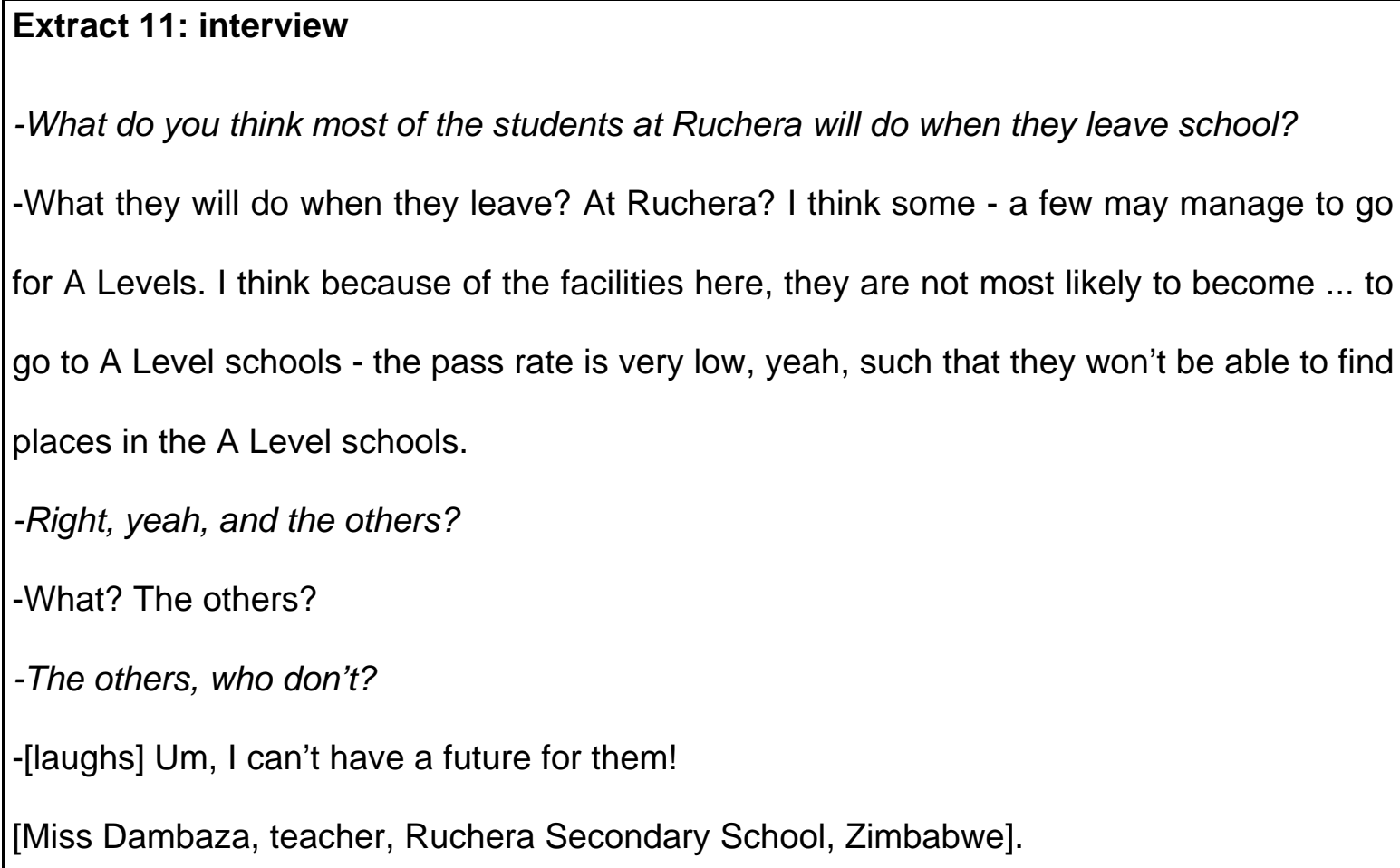


The objective of secondary education is so closely tied to certification that schools are not perceived to have a role in preparing those unable to obtain certificates with alternative routes to finding or creating employment. Teachers remain unaware of, or unconcerned with, the majority of students who will not figure in the COSC/O Level pass lists. Most students leaving school, especially girls, fail to obtain the employment they hope for. Of the 22 who completed Form E at Mahloko in 1996, only three passed COSC (see Table 1). 
Table 1: Student plans and outcomes, Form E, Mahloko High School ${ }^{8}$

\begin{tabular}{|c|c|c|}
\hline Name & Expectations, August-October 1996 & $\begin{array}{l}\text { Outcomes, August 1997-early } \\
1998\end{array}$ \\
\hline \multicolumn{3}{|l|}{ Girls } \\
\hline Mapuleng & $\begin{array}{l}\text { Nursing training/at home (hoping to } \\
\text { become a nun) }\end{array}$ & Repeating Form E in Maseru* \\
\hline Maseli & Temporary teacher/typing school & $\begin{array}{l}\text { Housewife (baby due imminently, } \\
\text { but had worked as temporary } \\
\text { teacher for a term) }\end{array}$ \\
\hline Pulane & Soldier/nursing training & $\begin{array}{l}\text { Seeking work (interview with } \\
\text { police) }\end{array}$ \\
\hline Nkareng & Repeating Form E/temporary teacher & At home, not working \\
\hline Lerato & Nursing training & $\begin{array}{l}\text { Seeking work/college place } \\
\text { (passed COSC) }\end{array}$ \\
\hline Mantoa & Repeating Form E & $\begin{array}{l}\text { Working at Likalaneng (dam } \\
\text { project)* }\end{array}$ \\
\hline Malineo & Temporary teacher, married & Maseru Co-operative College* \\
\hline Nketheleng & Nursing training/at home & $\begin{array}{l}\text { Applying to teacher training college } \\
\text { (passed cosc) }\end{array}$ \\
\hline Rosa & Repeating Form E/temporary teacher & Repeating Form E in Maseru \\
\hline Itumeleng & $\begin{array}{l}\text { At home, not working (hoping to } \\
\text { become a nun) }\end{array}$ & At home, seeking work \\
\hline Libuseng & $\begin{array}{l}\text { Repeating Form E/temporary } \\
\text { teacher/home }\end{array}$ & $\begin{array}{l}\text { Vocational school - leather } \\
\text { working* }\end{array}$ \\
\hline Malefu & Typing school/at home & At home, seeking work (interview \\
\hline
\end{tabular}




\begin{tabular}{|l|l|l|}
\hline & \multicolumn{2}{|l|}{ with police) } \\
\hline Puseletso & Nursing training/temporary teacher, & Married, not working* \\
\hline Boys & Not stated & \\
\hline Fusi & Doctor/dentist & Seeking work \\
\hline Mosiuoa & Soldier & Seeking work, applied to police \\
\hline Mahloua & Teacher & Petrol station \\
\hline Thabo & Not stated & Building \\
\hline Koaleli & Self-employed & At home, planning to study further \\
\hline Tlali & & (passed CosC) \\
\hline Ntsone & Office work & Building \\
\hline Tumisang & Car theft/smuggling & Soldier \\
\hline Taelo & Policeman & Child minder, to become soldier \\
\hline
\end{tabular}

Some of the girls described their efforts to find work. Pulane had been interviewed for a place at Police Training College. Three-hundred candidates were called for interview by radio, but only 24 men and 10 women were accepted. Other girls complained they were unable to make applications as their parents could not afford the stamps. The absence of telephones posed a further handicap. Some went to stay with relatives in Maseru to seek work.

The employment outcomes of secondary education for rural women was also apparent through interviews with rural women. Only six women resident in Muzunga had been employed since marriage, one following her husband's death, and another after divorce. Most reported having been unable to find formal sector work. 


\section{Conclusions}

Not only does secondary school attendance intervene directly in young people's transitions to adulthood, it also feeds on and contributes to a growing sense that adulthood is not itself fixed. Secondary education promotes an alternative 'modern' version of adulthood in which formal sector employment is central, but which has implications for adult lives that extend beyond the economic sphere. Education is less effective in enabling young people to make a transition to this alternative adulthood.

For a small minority of secondary school students, education culminates in the award of a certificate, which enables them to find formal sector employment. For successful girls, in particular, school provides not only the qualifications demanded by employers, but by focusing on certificates and employment as outcomes of education, and through a discourse of 'equal rights', promotes the view that women should enter the paid workforce. Although generally channelled into gender-stereotyped occupations, such women have the financial resources to satisfy their material needs and attain a degree of independence from parents, in-laws and husbands.

Not all of those who are relatively successful at school are able to obtain paid employment. Global economic change conspires with local conditions to deny many rural dwellers, particularly women, access to formal sector employment despite qualifications. Employers continue to favour men, and school does not greatly challenge notions of what is suitable work for women. Thus, in Lesotho, despite relative academic success, women still have greater difficulty finding employment, because they continue, to a large extent, to compete in separate labour markets from men. In particular, women are seldom able to gain entry to those (often manual) jobs, classed as male, which are common in rural areas and demand fewer paper qualifications. 
For the majority of school-leavers, known in Zimbabwe as 'Form-4-failers', there is very little chance of obtaining paid employment. Their parents have invested heavily in their education, in the hope of a high return (albeit knowing it was a risky investment), and the students have invested time, but they have not achieved the outcome towards which their experience of school was directed. School has provided them with almost no skills or knowledge of value in creating employment for themselves, and they are no better able to obtain work than those who only attended primary school.

The idea that there are alternative possible transitions to adulthood - that lifecourses are increasingly destandardised (Brannen and Nilsen 2002) - has pervaded recent Western youth studies. Rooted in the ideas of Beck (1994) and Giddens (1991), it is suggested that young people in 'late modernity' determine their own lifecourses to a much greater extent than in the past, choosing from varied options. In Lesotho and Zimbabwe, too, there are no longer prescribed lifecourses that everyone of a particular gender follows. However, whereas Hall et al (1999, p, 502) state that in the UK 'youth transitions in the 1990s are not only complex, but are increasingly young people's to decide upon', the choice for young southern Africans is somewhat illusory. While it appears that there is a choice: either stay at home and take on the traditional adult roles of spouse and parent, or pursue qualifications and become a worker in the formal sector with attendant benefits including independence, these two alternatives are not accorded equal merit. Those young people who attend secondary school are expected, and pressurised, to struggle towards the version of adulthood in which paid work is central, while the more 'conventional' lifestyle is cast as failure. Yet however hard young people might work to achieve the former, the inability of southern African economies to generate formal sector employment opportunities means that most will fail. 
France (2000) points out that where young people increasingly believe their personal biography is unique and their own responsibility, they also experience associated risks at the individual rather than collective level. In the past in southern Africa youth transitions involved little choice, and relatively little possibility of failure. Today, some young people feel responsible for their own failure to achieve the adulthood expected of them. Asked in a questionnaire her response to her COSC results, Itumeleng, a former Mahloko High School student wrote: ‘Disappointment because now I don't know where I will get the job. It seems as if I lost the whole of my parents' money.' It is inappropriate to understand youth transitions in southern Africa as entirely determined by a monolithic education system. Young people play a part in shaping their own, and others', experiences of education. However, the opportunities to achieve the goals that secondary schools encourage young people to pursue are severely constrained. Outcomes cannot match aspirations. Empirical research in England and Germany suggests young people struggle to take control of their lives, their agency bounded by both their socio-economic backgrounds and institutional environments (Evans 2002). In Lesotho and Zimbabwe, too, young people's agency is bounded, yet, unlike in the past, they are increasingly held responsible for the success of their transitions to adulthood.

\section{References}

Ansell, N (2002) "Of course we must be equal but... ': imagining gendered futures in two rural Southern African secondary schools' Geoforum 33, 179-194

Batezat, E and Mwalo, M (1989) Women in Zimbabwe. SAPES Trust, Harare

Beck, $U$ (1994) 'The reinvention of politics: towards a theory of reflexive modernization' in Beck U, Giddens A and Lash S (eds) Reflexive modernization Polity Press, Cambridge

Bennell, P and Malaba, J (1993) 'Up-dating rates of return to education: Zimbabwe in the late 1980s.' International Journal of Educational Development 13(3), 277-287 
Brannen, J and Nilsen, A (2002) 'Young people's time perspectives: from youth to adulthood' Sociology 36(3), 513-538

Cohen, P and Ainley, P (2000) 'In the country of the blind: youth studies and cultural studies in Britain' Journal of Youth Studies 3, 79-96

Dawson, D (1988) New horizons 4. Macmillan

Dore, R (1976) The diploma disease: education, qualification and development. George Allen and Unwin, London

Evans, K (2002) 'Taking control of their lives? Agency in young adult transitions in England and the new Germany' Journal of Youth Studies 5(3), 245-269

Ferguson, J (1990) The anti-politics machine: 'development', depoliticization and bureaucratic power in Lesotho. CUP, Cambridge

France, A (2000) 'Towards a sociological understanding of youth and their risk-taking' Journal of Youth Studies 3(3), 317-331

Gay, J, Gill, D and Hall, D (1995) Lesotho's long journey: hard choices at the crossroads: a comprehensive overview of Lesotho's historical, social, economic and political development with a view to the future. Sechaba Consultants, Maseru, Lesotho

Giddens, A (1991) Modernity and self-identity: self and society in the late modern age Stanford University Press, Stanford

Hall, T, Coffey, A and Williamson, H (1999) 'Self, space and place: youth identities and citizenship' British Journal of Sociology of Education 20(4), 501-513

Jones, G and Wallace, C (1992) Youth, family and citizenship Open University Press, Buckingham

King, E M and Hill, M A (eds) (1993) Women's education in developing countries: barriers, benefits and policies. John Hopkins University Press, Baltimore

Martin, C J (1982) 'Education and consumption in Maragoli (Kenya) households' educational strategies' Comparative Education 18(2), 139-155 
McDowell, L (2002) 'Transitions to work: masculine identities, youth inequality and labour market change' Gender, Place and Culture 9(1), 39-59

Ministry of Education (1982) The Education Sector Survey: Report of the Task Force.

Montsi, M R (1978) A study of the self-concept of Basotho male and female adolescents in secondary schools. DEd Thesis, University of Massachusetts

Psacharopoulos, G and Tzannatos, Z (1991) 'Female labour force participation.' in Psacharopoulos G (ed) Essays on poverty, equity and growth. Pergamon Press

Schultz, T P (1993) 'Investments in the schooling and health of women and men: quantities and returns.' Journal of human resources 28(4), 694-733

${ }^{1}$ An exception to this is in relation to childbirth, where 'failure' was a distinct possibility and had negative implications for those affected.

${ }^{2} \cos C$ is an exam that has, for many years, been set in the UK for use in former British colonies. A certificate is awarded to students who pass five subjects.

${ }^{3}$ Pseudonyms are used for schools, communities and research participants to preserve anonymity.

${ }^{4}$ The Zimbabwean research took place before the current economic crisis began.

${ }^{5} \mathrm{O}$ levels, like COSC, were developed in the UK in parallel with domestic secondary school qualifications, but in Zimbabwe these are now awarded by a local examination council. Only those who pass five or more subjects are awarded a certificate.

${ }^{6}$ Women with formal sector employment may be able to negotiate other improvements in their lives. Some working wives expect their husbands to share housework, if both are providing economic support to the household (Kimane 1979), and may also be able to negotiate safe sex (Mohale and Monasch 1995).

${ }^{7}$ The juxtaposed description of a man begins: 'At the age of 30, Vusi was of medium height, broad-shouldered, narrow-hipped and as lithe as a leopard' (Dawson 1988).

${ }^{8}$ Information on expectations was provided by individuals, directly. The girls talked of their plans in focus groups, and in August and again in October they wrote down what they expected to be doing in a year's time. The boys' expectations were expressed in a focus group. Information on girls' outcomes was provided, either by the 
students in person, in response to a postal questionnaire, or, where no response was received to the questionnaire (marked *), by other students/former students. For the boys, information was provided by other students. The 22 Form E students represent a fraction of those who entered Form A five years previously, many students having dropped out. 